\title{
Associations between iron deficiency anemia and clinical features among pregnant women: a prospective cohort study
}

\author{
Saeed Baradwan \\ Abdullah Alyousef \\ Abdulrhman Turkistani \\ Department of Obstetrics and \\ Gynecology, King Fahad Medical City, \\ Riyadh, Saudi Arabia
}

\begin{abstract}
This article was published in the following Dove Press journal: Journal of Blood Medicine

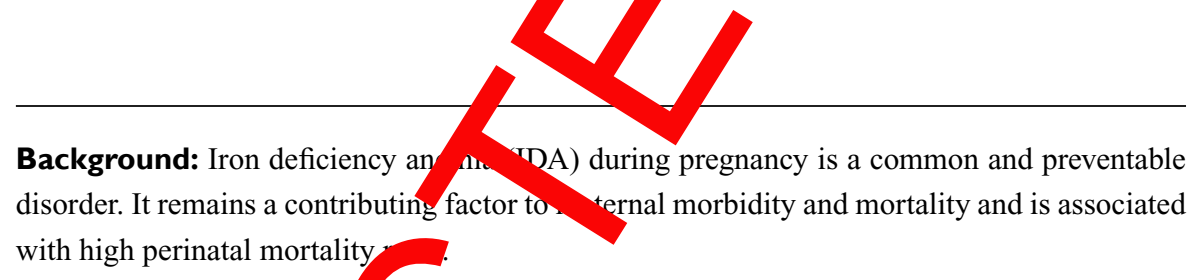
Objective: To determine re prevalep of IDA and its associated clinical features among pregnant women.

Methods: This analytical pro active co ort study included 1,579 pregnant women who attended an antenatal clinic, Women's Specralized Hospital, King Fahad Medical City, Riyadh, Saudi Arabia, between Jan Try 20 pril 2018. The type of anemia and its associated maternal and fetal outcomes we d crmined.

Results: Ab -92 won were confirmed to have IDA, with a prevalence of $44.5 \%$. Most women $(79 \%)$ w e young, than 35 years. A low hemoglobin concentration was reported in $45 \%$ of rticipa More than ho participants (57.3\%) reported use of iron supplementation during pregnanc IDA anemion highest in pregnant women with gravidity $>8$ in 40 (56.3\%) compared to on wregnant women 31 (43.7\%), and lowest in those with gravidity $\leq 2$ in $281(41.4 \%)$ compared to rmal pregnant women 397 (58.6\%). The difference was statistically significant, $P=0.024$. Similarly, this type of anemia was highest in those with parity of $>3(53.3 \%)$ and lowest nulliparous women (39.3\%) compared to normal pregnant women (46.7\%) and (60.7\%), This was statistically significant $P=0.002$. IDA had significantly $(P=0.012)$ lower nta ous vaginal delivery rates compared with normal pregnant women ( $44.5 \%$ vs $55.5 \%$, respeuively). IDA had significantly $(P=0.017)$ lower antenatal fetal distress rates compared normal pregnant women ( $68.5 \%$ vs $31.5 \%$, respectively).

Conclusion: Anemia in general and microcytic hypochromic anemia in particular were significantly associated with higher gravidity and parity. The significant outcome associated with IDA during pregnancy was a lower rate of spontaneous vaginal delivery and antenatal fetal distress. Compliance with iron supplementation in order to prevent maternal and fetal adverse outcomes was observed.

Keywords: microcytic hypochromic anemia, pregnancy, iron deficiency anemia

\section{Introduction}

Iron deficiency anemia (IDA) is the most common nutritional deficiency problem affecting pregnant women worldwide. ${ }^{1}$ The high prevalence of iron and other micronutrient deficiencies among women during pregnancy in developing countries is of concern, and maternal anemia is still a cause of considerable perinatal morbidity and mortality. ${ }^{2-4}$ Overall prevalence of iron deficiency in pregnant women in the US is
Correspondence: Saeed Baradwan Department of Obstetrics and Gynecology, Women's Specialized Hospital, King Fahad Medical City, PO Box 59046, Riyadh II525, Saudi Arabia Tel +966 II 2889999 (ext 10966) Email dr.saeed_bardwan@yahoo.com 
about $18 \%,{ }^{5}$ and in the UK, the prevalence was estimated to be $24 \%$ in a recent cross-sectional study. ${ }^{6}$

IDA in pregnancy has been defined by the National Academy of Sciences panel on nutrition and pregnancy as ferritin levels of less than $12 \mu \mathrm{g} / \mathrm{L} .{ }^{7}$ Serum ferritin may be a better indicator of iron status, as examination of iron stores in bone marrow is impractical. ${ }^{8}$ However, historically, blood hemoglobin $(\mathrm{Hb})$ levels have been used, this test being simple and inexpensive. The WHO defines anemia in pregnancy as $\mathrm{Hb}$ levels of less than $11 \mathrm{~g} / \mathrm{dL} .{ }^{9}$

Most women begin their pregnancy with partially or completely depleted iron reserves. ${ }^{10}$ During pregnancy, there is an increase in both red cell mass and plasma volume to accommodate the needs of the growing uterus and fetus. ${ }^{11}$ The plasma volume increases more than the red cell mass does, leading to a fall in the concentration of $\mathrm{Hb}$ in the blood, despite an increase in the total number of red cells. This drop in $\mathrm{Hb}$ concentration decreases blood viscosity and is thought to enhance placental perfusion, providing better maternal-fetal gas and nutrient exchange. ${ }^{12}$ Nonetheless, the significance of this physiological hemodily of pregnancy for women and their babies is controversic as is the level of $\mathrm{Hb}$ at which they would derive a benefi from iron treatment. ${ }^{13}$ Maternal iron requireme s av age $1,000 \mathrm{mg} / \mathrm{d} .^{14}$

Severe anemia during pregnancy results in mic al and fetal adverse outcomes. Maternal adverse atcomes in de preterm labor, preeclampsia, sepsis, post artu hemorrhage, and an increased need for blood transfusion. fetal adverse outcome consists of a high tal mortality rate at the third trimester of gestation. ${ }^{16}$ In ditio IDA of moderate degree can impact the motor ana ital de elopment of children and adolescents. ${ }^{17}$

In the present study, we med determine the prevalence of IDA in pregnant wome nd is associated clinical features by comparing these outcomes those of pregnant women with normal $\mathrm{Hb}$ levels.

\section{Methods}

An analytical prospective cohort study was carried out, which included 1,579 pregnant women who attended Women's Specialized Hospital, King Fahad Medical City, Riyadh, Saudi Arabia, between January 2018 and April 2018. We examined the hematological status and serum ferritin between 16 and 20 weeks of pregnancy. Exclusion criteria included malignancies, chronic renal or liver diseases, diabetic, hypertension disorder, known cases of thalassemia and hemoglobinopathies, vitamin B12 deficiency anemia, folic acid deficiency anemia, chronic inflammatory diseases, and having had a blood transfusion within 6 months before enrolment in the study.

Data were collected from the perinatal database, which consists of information collected uniformly according to predefined criteria immediately after delivery by an obstetrician. Coding is done after assessing the medical prenatal care record and the outine hospital documents. We analyzed the flowing ch acteristics: maternal age, gravidity, parity abo ans, ty $h$ pregnancy, medical history (diabete mellitus, hy rtension, and preeclampsia), and iron sur seme ation We also examined the following obstetric chà ristic apparent congenital malformation, in auterine th (defined as birth weight below the 5 cific 5 th percentile of weights for gestational age), antenatâ al distress, and mode of delivery (vaginal: aneous or induced, instrumental: forceps or ventouse, and cesare : elective or emergency). In addition, we invesigated ma crnal and perinatal outcomes: preterm labor (a d birth before 37 completed weeks of gestation), nostnartum hemorrhage, packed cell transfusion, maternal eath, Apgar score at 1 minute and 5 minutes, birth weight, admission to the neonatal intensive care unit (NICU), and erinatal mortality.

As study criteria, we used the WHO definition of anemia in pregnancy $(\mathrm{Hb} \text { levels of less than } 11 \mathrm{~g} / \mathrm{dL})^{9}$ and the definition by the National Academy of Sciences panel on nutrition and pregnancy of IDA (microcytic hypochromic anemia) in pregnancy (ferritin levels of less than $12 \mu \mathrm{g} / \mathrm{L}$ ). ${ }^{7}$ We recorded $\mathrm{Hb}$, hematocrit (HCT), red cell distribution width (RDW; erythrocyte volume), mean corpuscular volume (MCV), and mean corpuscular hemoglobin $(\mathrm{MCH})$. We then determined the types of anemia on the basis of these variables.

The protocol was reviewed and approved by the Institutional Review Board of King Fahad Medical City in Riyadh, Saudi Arabia. All data were entered into an electronic database without personal identifiers to maintain confidentiality. Patient consent was waived as no patient identifiers were included nor was the patient care affected or influenced in any way. This article does not contain any studies with animals performed by any of the authors.

The data were analyzed by using SPSS version 22.0. Demographic characteristics were expressed as mean $( \pm \mathrm{SD})$ and range. The outcome variables were expressed as the absolute number (percentage). The $P$-value was based on Fisher's exact test for categorical data and the Mann-Whitney $U$ test for quantitative variables. A $P$-value of $<0.05$ was considered to be statistically significant. 


\section{Results}

The study included 1,579 pregnant women. About 702 women were confirmed to have IDA, with a prevalence of $44.5 \%$. Patients' demographics are presented in Table 1. Most of the participants $(1,260$ [79.8\%]) were younger than 35 years. The median value of gravidity was 3 , ranged between 1 and 15; of parity was 2, ranged between 1 and 13; and of abortion was 1 , ranged between 1 and 11 . Intrauterine growth restriction was reported in 52 (3.3\%) participants and antenatal fetal distress in 73 (4.6\%) participants. Cesarean delivery was reported in 630 (39.9\%) participants, whereas instrumental or vacuum-assisted delivery was used in 66 (4.2\%). Spontaneous vaginal delivery was reported in almost half of the cases ( 883 [55.9\%]), and most of them were spontaneous (753 [47.7\%]). Emergency cesarean section was reported in $383(24.3 \%)$ cases. Preterm labor was reported in 191 $(12.1 \%)$ cases. The Apgar score at 1 minute ranged between 0 and 10 with a mean of $9.2 \pm 1.6$, whereas that at 5 minutes ranged between 0 and 9 with a mean of $8.2 \pm 1.6$. Apparent congenital malformation was observed in 51 (3.2\%), admission to NICU in $136(8.6 \%)$, postpartum hemorrhage if (3.7\%), and intrauterine fetal death in $29(1.8 \%)$ cases.

From Table 1, low level of $\mathrm{Hb}$ concentration was manorted in 711 (45\%) participants, low HCT values in 97 (61) \%), and low RDW values in 52 (3.4\%). The MCH uncen mur was below normal in $10.8 \%$ of the cases. The fer h level was low in $702(45 \%)$ cases. The MCV wa below norm in $486(30.7 \%)$ and the mean corpuscular $\mathrm{H}$ Was ow normal in $531(33.6 \%)$ cases. The major renorted type o nemia was microcytic hypochromic anen a (702 [98.7\%]). More than half of the participants $\left(90557.3^{\circ}\right.$, repo thed the use of iron supplementation during pres cy. Tb birth weight of the first baby was $2.99 \pm 0$ and ane twin babies was $2.15 \pm 0.67 \mathrm{~kg}$.

From (Table 2), it is ev nt at the studied factors could be associated with IDA. IDA an ia was highest in pregnant women with gravidity $>8$ at 40 years $(56.3 \%)$ compared to normal pregnant women at 31 years $(43.7 \%)$, and lowest in those with gravidity $\leq 2(281[41.4 \%])$ compared to normal pregnant women (397 [58.6\%]). The difference was statistically significant $(P=0.024)$. Similarly, this type of anemia was highest in those with parity of $>3(53.3 \%)$ and lowest in nulliparous women (39.3\%) compared to normal pregnant women $(46.7 \%)$ and $(60.7 \%)$, respectively. This was statistically significant $(P=0.002)$. IDA had significantly $(P=0.012)$ lower spontaneous vaginal delivery rates compared with normal pregnant women ( $44.5 \%$ vs $55.5 \%$, respectively). This anemia was reported in more than half of the women
(132 [54.3\%]) who delivered by elective cesarean section, in $153(40.2 \%)$ of those who delivered by emergency cesarean section, and in $32(50 \%)$ of those who delivered by ventouse. IDA had significantly $(P=0.017)$ lower antenatal fetal distress rates compared with normal pregnant women $(68.5 \%$ vs $31.5 \%$, respectively). There is some missing data in this study parameter and hence is not included in this analysis. IDA was not signific aly ass ated with other maternal and fetal characteristic as illustrat in Table 2.

\section{Discussig}

The prevale ce of nemia ras reported to be the highest in Indian women $9 \%$, vile it was $16 \%$ in black Caribbean women and 6\%-7\% Irish and Chinese women. In this study the valence was $44.5 \%$, which is slightly higher than that reported in se countries, and the prevalence based on N TICT was $61.9 \%$, which is higher than that reported in European o intries (at about 50\%). ${ }^{19,20} \mathrm{~A}$ higher gravidity and arity was $y$ ported in women with anemia in general and IDA in pu ar. Similar results have been reported previously. ${ }^{19}$ Much of the information regarding IDA in pregnancy Ind its adverse outcomes is controversial. Two important points should be considered: the gestational age at which the etermination of $\mathrm{Hb}$ is performed and the degree of anemia identified. Regarding the first point, throughout the first and second trimesters of pregnancy, $\mathrm{Hb}$ and HCT levels decline because of the physiological expansion of plasma volume. ${ }^{21}$ Late in the second to early third trimester, $\mathrm{Hb}$ and $\mathrm{HCT}$ levels reaches its lowest level and then rises again nearer to term. Therefore, the best time to detect any risk associated with maternal anemia would be early in pregnancy, a fact that has been demonstrated in many studies. ${ }^{22,23}$ Thus, any estimation of $\mathrm{Hb}$ concentration after 20 weeks of gestation is reasonably representative of the fall in concentration induced by pregnancy. ${ }^{24}$

The second point that should be considered is IDA during pregnancy, as the association with adverse pregnancy outcomes is also controversial. The association between IDA and birth weight has been documented, as has been the association between IDA and preterm delivery. ${ }^{25}$ However, in the present study, anemia was significantly associated with a lower rate of spontaneous vaginal delivery. This finding might be attributed to the fact that anemia in our study was mostly mild and most participants were taking iron supplements. In agreement with others, we assume that iron supplementation during pregnancy may have a protective effect against adverse outcomes. On the other hand, it has been reported in several studies that severe maternal anemia in the first trimester is 
Table I Characteristics of I,579 study subjects

\begin{tabular}{|c|c|c|}
\hline Characteristics & Characteristics & $n(\%)^{a}$ \\
\hline \multirow[t]{2}{*}{ Mother's age, years } & $<35$ & $\mathrm{I}, 260(79.8)$ \\
\hline & $\geq 35$ & $319(20.2)$ \\
\hline \multirow[t]{6}{*}{ Gravida } & $\mathrm{I}-2$ & $685(43.4)$ \\
\hline & $3-4$ & $475(30.1)$ \\
\hline & $5-6$ & $254(16.1)$ \\
\hline & $7-8$ & $92(5.8)$ \\
\hline & $>8$ & $73(4.6)$ \\
\hline & Median (min, max) & $3(1,15)$ \\
\hline \multirow[t]{4}{*}{ Parity } & Nulliparous & $428(27.1)$ \\
\hline & $1-3$ & $900(57.0)$ \\
\hline & $>3$ & $251(15.9)$ \\
\hline & Median (min, max) & $2(I, 13)$ \\
\hline \multirow[t]{4}{*}{ Abortions } & No & $\mathrm{I}, 044(66 . \mathrm{I})$ \\
\hline & $\mathrm{I}-3$ & $484(30.7)$ \\
\hline & $>3$ & $5 I(3.2)$ \\
\hline & Median (min, max) & $I(I, I I)$ \\
\hline Intrauterine growth restriction & & $52(3.3)$ \\
\hline Antenatal fetal distress & & $73(4.6)$ \\
\hline \multirow[t]{3}{*}{ Mode of delivery } & Vaginal & $883(55.9)$ \\
\hline & Cesarean & $630(39.9)$ \\
\hline & Instrumenta & $66(4.2)$ \\
\hline \multirow[t]{2}{*}{ Type of cesarean } & Elective & $249(15.8)$ \\
\hline & Emergency & $383(24.3)$ \\
\hline \multirow[t]{2}{*}{ Type of vaginal delivery } & Spontaneous & $753(47.7)$ \\
\hline & Induced & $128(8.1)$ \\
\hline \multirow[t]{2}{*}{ Type of instrumental delivery } & Forceps & $2(0.1)$ \\
\hline & & $64(4.1)$ \\
\hline Preterm labor & & $191(12.1)$ \\
\hline Maternal death & & $0(0.0)$ \\
\hline \multirow[t]{4}{*}{ I-minute Apgar score } & & $\mathrm{I}, 46 \mathrm{I}(92.5)$ \\
\hline & & $51(3.2)$ \\
\hline & & $67(4.2)$ \\
\hline & & $9.2 \pm 1.6(0,10)$ \\
\hline \multirow[t]{4}{*}{ 5-minute Apgar score } & $\geq 7$ & I,529 (96.8) \\
\hline & & $38(2.4)$ \\
\hline & & $12(.8)$ \\
\hline & i & $8.2 \pm 1.6(0,9)$ \\
\hline Twin pregnancy & & $66(4.2)$ \\
\hline Apparent congenital malformat & & $51(3.2)$ \\
\hline Admission to NICU & & $136(8.6)$ \\
\hline Postpartum hemorrhage & & $59(3.7)$ \\
\hline Intrauterine fetal death & & $29(1.8)$ \\
\hline \multirow[t]{3}{*}{$\mathrm{Hb}$} & Normal & $867(54.9)$ \\
\hline & Low & $711(45.0)$ \\
\hline & High & $I(0.0)$ \\
\hline \multirow[t]{3}{*}{ HCT } & Normal & $601(38)$ \\
\hline & Low & $975(61.9)$ \\
\hline & High & $3(.2)$ \\
\hline \multirow[t]{3}{*}{ Ferritin level } & Normal & $868(54.9)$ \\
\hline & Low & $702(45)$ \\
\hline & High & $9(0.9)$ \\
\hline \multirow[t]{3}{*}{ RDW (erythrocyte volume) } & Normal & $\mathrm{I}, 100(69.6)$ \\
\hline & Low & $52(3.4)$ \\
\hline & High & $427(27)$ \\
\hline
\end{tabular}


Table I (Continued)

\begin{tabular}{|c|c|c|}
\hline & Characteristics & n (\%) ${ }^{a}$ \\
\hline \multirow[t]{3}{*}{ MCV } & Normal & $\mathrm{I}, 068(68)$ \\
\hline & Low & $486(30.7)$ \\
\hline & High & $25(1.3)$ \\
\hline \multirow[t]{3}{*}{$\mathrm{MCH}$} & Normal & $986(62.8)$ \\
\hline & Low & $531(33.6)$ \\
\hline & High & $62(3.6)$ \\
\hline \multirow[t]{3}{*}{ Anemia type } & Normal $(\mathrm{MCV}+\mathrm{MCH}):$ Normocytic normc & $2(0.3)$ \\
\hline & Low $(\mathrm{MCV}+\mathrm{MCH})$ : Microcytic hypochro & $702(98.7)$ \\
\hline & High $(\mathrm{MCV}+\mathrm{MCH})$ : Macrocytic hyperchro & $7(1.0)$ \\
\hline \multirow[t]{3}{*}{ MCHC (erythrocyte) } & Normal & I,379 (87.3) \\
\hline & Low & $170(10.8)$ \\
\hline & High & $30(1.9)$ \\
\hline \multirow[t]{2}{*}{ Iron used } & No & $674(42.8)$ \\
\hline & Yes & $905(57.3)$ \\
\hline Birth weight $(\mathrm{kg})$ of first baby & Mean $\pm S D(\min , \max )$ & $2.99 \pm 0.64(0.32,6.32)$ \\
\hline Birth weight $(\mathrm{kg})$ of twin baby & Mean \pm SD $(\min , \max )$ & $2.15 \pm 0.67(0.41,3.28)$ \\
\hline
\end{tabular}

Abbreviations: $\mathrm{Hb}$, hemoglobin; $\mathrm{HCT}$, hematocrit; $\mathrm{MCH}$, mean corpuscular hemoglobin: $\mathrm{M} C \mathrm{HC}$, mean corpurcular hemoglobin concentration; $\mathrm{MCV}$, mean corpuscular volume; NICU, neonatal intensive care unit; RDW, red cell distribution width.

Table 2 Microcytic hypochromic anemia (MHA) in study sú

\begin{tabular}{|c|c|c|c|c|}
\hline Characteristics & & Normal $(n=867)^{a}$ & MHA $(n=702)^{a}$ & $P$-value \\
\hline \multirow[t]{2}{*}{ Mother's age, years } & $<35$ & $692(55.5)$ & $555(44.5)$ & $0.38 \mathrm{I}$ \\
\hline & $\geq 35$ & $164(52.7)$ & I47 (47.3) & \\
\hline \multirow[t]{5}{*}{ Gravida } & $\mathrm{I}-2$ & $397(58.6)$ & $28 I(4 I .4)$ & 0.024 \\
\hline & $3-4$ & $259(55.3)$ & $209(44.7)$ & \\
\hline & $5-6$ & $123(49.4)$ & $126(50.6)$ & \\
\hline & 7 & $46(50.0)$ & $46(50.0)$ & \\
\hline & & $31(43.7)$ & $40(56.3)$ & \\
\hline \multirow[t]{3}{*}{ Parity } & rous & $256(60.7)$ & $166(39.3)$ & 0.002 \\
\hline & & $485(54.5)$ & $405(45.5)$ & \\
\hline & & II 5 (46.7) & $131(53.3)$ & \\
\hline \multirow[t]{3}{*}{ Abortions } & & $579(56.2)$ & $452(43.8)$ & 0.374 \\
\hline & & $252(52.8)$ & $225(47.2)$ & \\
\hline & & $25(50.0)$ & $25(50.0)$ & \\
\hline \multirow[t]{2}{*}{ Gestational age, weeks } & 37 & $755(54.5)$ & $631(45.5)$ & 0.291 \\
\hline & & $101(58.7)$ & $7 I(4 I .3)$ & \\
\hline \multirow[t]{2}{*}{ Intrauterine growth restriction } & No & $825(54.7)$ & $682(45.3)$ & 0.394 \\
\hline & & $31(60.8)$ & $20(39.2)$ & \\
\hline \multirow[t]{2}{*}{ Antenatal fetal distress } & No & $806(54.3)$ & $679(45.7)$ & 0.017 \\
\hline & Yes & $50(68.5)$ & $23(31.5)$ & \\
\hline \multirow[t]{3}{*}{ Mode of delivery } & Vaginal & $485(55.7)$ & $385(44.3)$ & 0.709 \\
\hline & Cesarean & $337(54.2)$ & $285(45.8)$ & \\
\hline & Instrumental or vacuum assisted & $34(5 \mid .5)$ & $32(48.5)$ & \\
\hline \multirow[t]{6}{*}{ Delivery type } & Elective CS & III (45.7) & $132(54.3)$ & 0.012 \\
\hline & Emergency CS & $228(59.8)$ & $153(40.2)$ & \\
\hline & Forceps & $2(100.0)$ & $0(0)$ & \\
\hline & Induced & $72(56.3)$ & $56(43.8)$ & \\
\hline & Spontaneous & $4 I I(55.5)$ & $329(44.5)$ & \\
\hline & Ventouse & $32(50.0)$ & $32(50.0)$ & \\
\hline \multirow[t]{2}{*}{ Preterm labor } & No & $753(54.8)$ & $622(45.2)$ & 0.698 \\
\hline & Yes & $103(56.3)$ & $80(43.7)$ & \\
\hline
\end{tabular}


Table 2 (Continued)

\begin{tabular}{|c|c|c|c|c|}
\hline Characteristics & & Normal $(n=867)^{a}$ & MHA $(n=702)^{a}$ & $P$-value \\
\hline \multirow[t]{2}{*}{ Admission to NICU } & No & $854(55.0)$ & $698(45.0)$ & 0.286 \\
\hline & Yes & $2(33.3)$ & $4(66.7)$ & \\
\hline \multirow[t]{2}{*}{ Maternal death } & No & $855(54.9)$ & $702(45.1)$ & \\
\hline & Yes & $0(.0)$ & $0(.0)$ & \\
\hline \multirow[t]{3}{*}{ I-minute Apgar score } & $\geq 7$ & $801(55.5)$ & $643(44.5)$ & 0.289 \\
\hline & $0-3$ & $24(5 I . I)$ & $23(48.9)$ & \\
\hline & $4-6$ & $31(46.3)$ & $36(53.7)$ & \\
\hline \multirow[t]{3}{*}{ 5-minute Apgar score } & $\geq 7$ & $831(55.0)$ & I (45.0) & 0.946 \\
\hline & $0-3$ & $18(52.9)$ & $(47.1)$ & \\
\hline & $4-6$ & $7(58.3)$ & $(4 I .7)$ & \\
\hline \multirow[t]{2}{*}{ Birth weight (kg) } & $\geq 2.5$ & $721(54$ & $603(45.5)$ & 0.359 \\
\hline & $<2.5$ & 135 & $99(42.3)$ & \\
\hline \multirow[t]{2}{*}{ Twin pregnancy } & No & & $674(45.2)$ & 0.66 \\
\hline & Yes & & $28(42.4)$ & \\
\hline \multirow[t]{2}{*}{ Apparent congenital malformation } & No & 9) & $679(45.1)$ & 0.995 \\
\hline & Yes & & $23(45.1)$ & \\
\hline \multirow[t]{2}{*}{ Admission to NICU } & No & 7 & $650(45.7)$ & 0.126 \\
\hline & Yes & $82(61.2)$ & $52(38.8)$ & \\
\hline \multirow[t]{2}{*}{ Postpartum hemorrhage } & No & $819(54.6)$ & $681(45.4)$ & 0.167 \\
\hline & Yes & $37(48)$ & $21(36.2)$ & \\
\hline \multirow[t]{2}{*}{ Intrauterine fetal death } & No & $842(5.0)$ & $689(45.0)$ & 0.745 \\
\hline & Yes & & $13(48.1)$ & \\
\hline \multirow[t]{2}{*}{ Iron used } & No & $38 \mathrm{I}(57.5)$ & $282(42.5)$ & 0.14 \\
\hline & Yes & $473(53.0)$ & $420(47.0)$ & \\
\hline
\end{tabular}

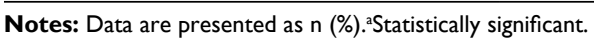

Abbreviation: NICU, neonatal intensive care unit; CS, cesarean section.

associated with adverse outcomes suc as oterm birth, intrauterine growth restriction, low birth weight, to Apgar score, and cesarean deliveries. ${ }^{26-3}$

The association between IDA and ad erse o ycomes has been confirmed in many studies. ${ }^{20}$ n a st ry conducted by Patra et al, ${ }^{31}$ very high al mon aty (6.2\%) and perinatal mortality (60\%) ere ob enrodin severely anemic women during the third tim of of pregnancy. Most women in the present study were at a ational age of $>37$ weeks and had mild anemia, which might explain the absence of an association of anemia with adverse outcomes, other than the relatively lower rate of antenatal fetal distress.

The limitations of our study were that it was limited to Women's Specialized Hospital, and some data regarding the study parameter were missing. Also, we did not classify IDA into mild or severe. We recommend that information, education, and counseling about this disease be provided to pregnant women. This information might aid physicians in guiding their patients and taking optimal clinical decisions together.

In conclusion, IDA during pregnancy continues to be a major health problem worldwide. Anemia in general and microcytic hypochromic anemia in particular are significantly associated with higher gravidity and parity. The significant outcome associated with IDA during pregnancy was a lower rate of spontaneous vaginal delivery and antenatal fetal distress. Compliance with iron supplementation in order to prevent maternal and fetal adverse outcomes was observed.

In light of these results, we recommend hematological screening for $\mathrm{Hb}$ and iron status in early pregnancy. There is no need for further checks of these values if the pregnancy is uncomplicated and there is compliance with iron supplementation to prevent maternal and fetal adverse outcomes.

\section{Disclosure}

The authors report no conflicts of interest in this work.

\section{References}

1. Miller JL. Iron deficiency anemia: a common and curable disease. Cold Spring Harb Perspect Med. 2013;3(7):a011866.

2. UNICEF/UNU/WHO. Iron Deficiency Anemia: Assessment, Prevention, and Control. Geneva: World Health Organization; 2001.

3. Thangaleela T, Vijayalakshmi P. Prevalence of anaemia in pregnancy. Indian J Nutr Diet. 1994;31:26-32. 
4. Cutner A, Bead R, Harding J. Failed response to treat anaemia in pregnancy: reasons and evaluation. JObstet Gynecol. 1999;Suppl 1:S23-27.

5. Mei Z, Cogswell ME, Looker AC, et al. Assessment of iron status in US pregnant women from the National Health and Nutrition Examination Survey (NHANES), 1999-2006. Am J Clin Nutr. 2011;93(6):1312-1320.

6. Barroso F, Allard S, Kahan BC, et al. Prevalence of maternal anaemia and its predictors: a multi-centre study. Eur J Obstet Gynecol Reprod Biol. 2011;159(1):99-105.

7. Institute of Medicine, Committee on Nutritional Status During Pregnancy and Lactation. Nutrition During Pregnancy. Washington, DC: National Academy Press; 1990:272-298.

8. Hoffman R, Benz E, Shattil SJ, Furie B, Cohen HJ, Silberstein LE. Hematology: Basic Principles and Practice. 3rd ed. New York: Churchill Livingstone, Inc; 2000.

9. World Health Organization. Iron Deficiency Anaemia, Assessment, Prevention and Control: A Guide for Programme Managers. Geneva: WHO; 2001.

10. Robson SC, Hunter S, Boys RJ, Dunlop W. Serial study of factors influencing changes in cardiac output during human pregnancy. Am J Physiol. 1989;256(4 Pt 2):H1060-H1065.

11. Duvekot JJ, Cheriex EC, Pieters FA, Menheere PP, Peeters LH. Early pregnancy changes in hemodynamics and volume homeostasis are consecutive adjustments triggered by a primary fall in systemic vascular tone. Am J Obstet Gynecol. 1993;169(6):1382-1392.

12. Prakash S, Yadav K. Maternal anemia in pregnancy: an overview. Ijppr Human. 2015;4(3):164-179.

13. Al RA, Unlubilgin E, Kandemir O, Yalvac S, Cakir L, Haberal A. Intravenous versus oral iron for treatment of anemia in pregnancy: a randomized trial. Obstet Gynecol. 2005;106(6):1335-1340.

14. Bothwell TH. Iron requirements in pregnancy and strategies to $\mathrm{h}$ them. Am J Clin Nutr. 2000;72(1 Suppl):257S-264.

15. Bayoumeu F, Subiran-Buisset C, Baka NE, Legagneur H MonnierBarbarino P, Laxenaire MC. Iron therapy in iron deficier an ia in pregnancy: intravenous route versus oral route. Am J 2002;186(3):518-522.

16. Khan MM. Effect of maternal anaemia on fetal paramete $\mathrm{ub} \mathrm{Med}$ Coll Abbottabad. 2001;13(2):38-41.

17. Halterman JS, Kaczorowski JM, Aligne CA, Aui r., Szilagyi PG. on deficiency and cognitive achievement among noo ed children and adolescents in the United States. Pediatrics. 2001;107(0, 81-1386.

18. Algarín C, Peirano P, Garrido M, Pizarro , Lozoff B. Iron auficiency anemia in infancy: long-lasting effects auditry and visual system functioning. Pediatr Res. 2003;53(2

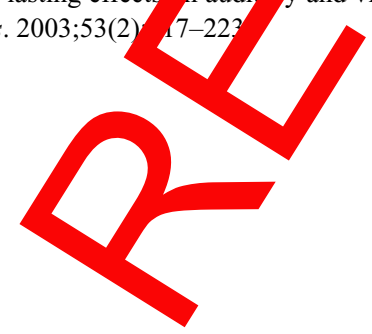

19. Bencaiova G, Breymann C. Mild anemia and pregnancy outcome in a Swiss collective. Journal of Pregnancy. 2014; 307535:7.

20. Hercberg S, Preziosi P, Galan P. Iron deficiency in Europe. Public Health Nutr. 2001;4(2B):537-545.

21. Mcmullin MF, White R, Lappin T, Reeves J, Mackenzie G. Haemoglobin during pregnancy: relationship to erythropoietin and haematinic status. Eur J Haematol. 2003;71(1):44-50.

22. Levy A, Fraser D, Katz M, Mazor M, Sheiner E. Maternal anemia during pregnancy is an independent risk factor for low birthweight and preterm dew Eur J Obstet Gynecol Reprod Biol. 2005;122(2):182-18

23. Xiong X, Buekens Alexander S, emianczuk N, Wollast E. Anemia during pregnancy a birth outcom a meta-analysis. Am J Perinatol. 2000;17(3):137 146 .

24. Steer P, Alam A, Wadswor Nelch A. Relation between maternal haemoglob concer ation and birth weight in different ethnic groups. BMJ. 199 <10(69 8):489 1 .

25. Rasmuasen $\Lambda$ here a asal Relationship between Iron Deficiency or Irs Deficiency a and Weight at Birth, Length of Gestation and rinatal Mortality J Nutr. 2001;131(2S-2):590S-603.

26. Z u Lm ang WW, Hua JZ, Deng CQ, Tao X, Stoltzfus RJ. Relation or hemoglob neasured at different times in pregnancy to preterm in and low brth weight in Shanghai, China. Am J Epidemiol. 1998;148(10):998-1006.

27. Malhotra M, Sharma JB, Batra S, Sharma S, Murthy NS, Arora R. Maternal id perinatal outcome in varying degrees of anemia. Int $J$ Gynaec Obstet. 2002;79(2):93-100.

28. Fraser D, Katz M, Mazor M, Sheiner E. Maternal anemia during pregnancy is an independent risk factor for low birthSht and preterm delivery. Eur J Obstet Gynecol Reprod Biol. 2005;122(2):182-186.

29. Xiong X, Buekens P, Alexander S, Demianczuk N, Wollast E. Anemia during pregnancy and birth outcome: a meta-analysis. Am J Perinatol. 2000;17(3):137-146.

30. Fareh OI, Rizk DE, Thomas L, Berg B. Obstetric impact of anaemia in pregnant women in United Arab Emirates. J Obstet Gynaecol. 2005;25(5):440-444.

31. Patra S, Pasrija S, Trivedi SS, Puri M. Maternal and perinatal outcome in patients with severe anemia in pregnancy. Int $J$ Gynaecol Obstet 2005;91(2):164-165.

32. Scanlon KS, Yip R, Schieve LA, Cogswell ME. High and low hemoglobin levels during pregnancy: differential risks for preterm birth and small for gestational age. Obstet Gynecol. 2000;96(5 Pt 1):741-748.

\section{Journal of Blood Medicine}

\section{Publish your work in this journal}

The Journal of Blood Medicine is an international, peer-reviewed, open access, online journal publishing laboratory, experimental and clinical aspects of all aspect pertaining to blood based medicine including but not limited to: Transfusion Medicine; Blood collection, Donor issues, Transmittable diseases, and Blood banking logistics; Immunohematology; Artificial and alternative blood based therapeutics; Hematology; Biotechnology/nanotechnology of blood related medicine; Legal aspects of blood medicine; Historical perspectives. The manuscript management system is completely online and includes a very quick and fair peer-review system. Visit http://www.dovepress.com/ testimonials.php to read real quotes from published authors. 